\title{
KETERKAITAN EFISIENSI OPERASIONAL DAN PEMBIAYAAN BERMASALAH DALAM MEMPENGARUHI PROFITABILITAS BANK UMUM SYARIAH
}

\author{
Nugrahini Kusumawati \\ Ani Setianingsih
}

Fakultas Ekonomi dan Bisnis, Universitas Bina Bangsa

Email: innanugrahini@gmail.com; ani.setianingsih01@gmail.com

\begin{abstract}
The aimed of this study is to examine the influence of operational efficiency and Non Performing Financing of The Shariah Bank toward profitability. This study uses secondary data obtained from the annual report contained in Bank Indonesia. The sample in this study used 8 sharia commercial banks registered in Bank Indonesia in 2012-2016. Samples were chosen using purposive sampling methods. The hypothesis was tested using multiple regression. The first hypothesis was used to examine the influence of operation efficiency to profitability. The second hypothesis was used to examine the influence of Non Performance Financing to profitability. The third hypothesis was used to examine the influence of Operational Efficiency and Non Performance Financing to profitability. The result of the research shows that the operational efficiency have an effect on profitability. Bu toperational efficiency have not an effect on profitability. Simultaneously operational efficiency and Non Performance Financing have an effect on profitability.
\end{abstract}

Keywords: Operational Efficiency, Non Performing Financing, and profitability.

\section{PENDAHULUAN}

Industri perbankan di Indonesia merupakan salah satu lembaga yang mempunyai peranan penting dalam menunjang perekonomian di Indonesia. Hal ini dikarenakan perbankan merupakan penghimpun dana dari msyarakat dalam bentuk simpanan dan menyalurkannya pada masyarakat dalam bentuk kredit dan bentuk lainnya dalam rangka meningkatkan taraf hidup masyarakat. Perkembangan industri perbankan diawali dengan adanya industri perbankan konvensional. Namun berjalannya waktu masyarakat muslim di Indonesia menyadari bahwa perbankan konvensional cenderung kepada riba. Seperti yang disampaikan dalam penelitian Zakiy, Ridwan dan Sani (2018) menyatakan bahwa "Modern lifestyle has great impact to the economy of 
moslem families. To come over this situation, the moslem families should hold towards the principles of syariah as mentioned in Al-Qur'an and Hadits. This kind of economy could deliver positive impact, peacefulness, and harmony within the moslem families". Dalam era modern yang serba mudah dan terbuka ini keluarga muslim harus berpegang pada prinsipprinsip syariah seperti yang disebutkan dalam Al-Qur'an dan Hadits. Kesadaran tersebut yang membuat perkembangan perekonomian di Indonesia mulai muncul industri perbankan syariah yang sampai saat ini semakin berkembang dan semakin memperlihatkan eksistensinya dalam perekonomian nasional.

Perkembangan perbankan syariah di Indonesia telah menjadi tolak ukur keberhasilan pertumbuhan dan eksistensi ekonomi syariah. Dalam beberapa tahun terakhir bank-bank syariah tumbuh sangat pesat sekali di Indonesia. Seperti yang diungkapkan oleh Sani (2013) "The emergence and development of the syariah banks began from the issuing of the October Policies which managed the deregulation of the banking industry in Indonesia. The emergence of syariah banks in Indonesia is an interesting phenomenon and is the highest point of the long effort by some individual (scholars and intellectuals) both individually and institutionally in the process of social transformation". Saat ini, pertumbuhan perbankan syariah diIndonesia mengalami kemajuan yang cukup pesat. Salah satu faktornya disebabkan oleh dukungan permintaan islamic product dari penduduk Indonesia yang sebagian besar adalah muslim. Perkembangan perbankan syariah di Indonesia dikatakan cukup pesat, hal ini terlihat dari data total aset yang dipublikasikan oleh Bank Indonesia:

Tabel 1

Perkembangan Aset Bank Umum Syariah (Triliun Rupiah)

\begin{tabular}{|c|c|c|}
\hline No & Tahun & Jumlah \\
\hline 1 & 2012 & 195.018 \\
\hline 2 & 2013 & 242.276 \\
\hline 3 & 2014 & 272.343 \\
\hline 4 & 2015 & 296.262 \\
\hline 5 & 2016 & 356.504 \\
\hline 6 & 2017 & 424.181 \\
\hline
\end{tabular}

Sumber : http://www.bi.go.id 
Tabel 1 menunjukan bahwa total aset yang disalurkan bank syariah mengalami peningkatan dari tahun ke tahunya.Keberadaan Bank syariah diharapkan dapat mendorong dan mempercepat kemakmuran ekonomi masyarakat melalui kegiatan perbankan, pembiayaan, dan investasi sesuai kaidah islam. Oleh karena itu Bank Syariah perlu meningkatkan kinerjanya jauh lebih baik lagi. Profitabilitas merupakan indikator yang paling tepat untuk mengukur kinerja suatu bank. Salah satu untuk mengukur tingkat profitabilitas bank adalah dengan menggunakan Return On Assets (ROA) karena Bank Indonesia sebagai pembina dan pengawas perbankan lebih mengutamakan nilai profitabilitas suatu bank yang di ukur dari aset yang dananya berasal dari sebagian besar dana simpanan masyarakat. Semakin besar Return On Asset suatu bank, semakin besar pula tingkat keuntungan yang dicapai bank dan semakin baik posisi bank tersebut dari segi penggunaan aset.

Perlu usaha dalam menjaga pertumbuhan profitabilitas Bank Syariah dengan melihat faktor-faktor yang mempengaruhinya, sehingga dimungkinkan adanya usaha dalam mendorong pertumbuhan profitabilitas ke arah yang lebih baik. Pengetahuan tentang faktor-faktor yang mempengaruhi profitabilitas dapat mendorong nilai profitabilitas menjadi lebih tinggi pada saat berpotensi menguat dan menjaganya agar tidak mengalami penurunan pada saat berpotensi melemah.

Semakin tinggi profitabilitas bank syariah maka semakin baik pula kinerja bank tersebut. Kinerja bank syariah dapat dinilai melalui berbagai macam variabel yang diambil dari laporan keuangan bank syariah. Laporan keuangan tersebut menghasilkan sejumlah rasio keuangan yang dapat membantu para pemakai laporan keuangan dalam menilai kinerja bank syariah. Oleh karena itu, perlu kiranya mengidentifikasi rasio keuangan yang mempengaruhi profitabilitas diantaranya yaitu efisiensi operasional dan pembiayaan bermasalah. Tabel 2 berikut ini menyajikan perkembangan rata-rata rasio keuangan Bank Umum Syariah di Indonesia selama periode 2012-2016. 
Tabel 2

Perkembangan ROA, BOPO, dan NPFBank Umum Syariah (dalam \%)

\begin{tabular}{|c|c|c|c|c|c|c|}
\hline Variabel & 2012 & 2013 & 2014 & 2015 & 2016 & 2017 \\
\hline ROA & 2.14 & 2.00 & 0,41 & 0,49 & 0.63 & 0.63 \\
\hline BOPO & 74.97 & 78.21 & 96.97 & 97.01 & 96.22 & 94.91 \\
\hline NPF & 2.22 & 2.62 & 4.95 & 4.84 & 4.42 & 4.77 \\
\hline
\end{tabular}

Sumber : http://www.ojk.go.id

Berdasarkan tabel 2 diatas, nilai ROA, BOPO dan NPF mengalami kecenderungan berfluktuasi dari tahun ke tahun. Hal ini menunjukkan bahwa kinerja perbankan syariah dipengaruhi oleh faktor eksternal dan internal.

Penelitian mengenai rasio keuangan dan pengaruhnya terhadap profitabilitas bank di Indonesia telah dilakukan oleh beberapa peneliti, namun tidak konsisten hasilnya.Penelitian yang dilakukan Bambang (2010) menunjukkan bahwa pembiayaan bermasalah berpengaruh negative terhadap dan signifikan terhadap profitabilitas. Sedangkan hasil penelitian Wibowo dan Syaichu (2013) besar kecilnya pembiayaan bermasalah yang diderita oleh Bank Syariah tidak akan mempengaruhi kemampuan Bank Syariah dalam mengahasilkan laba. Pembiayaan yang disalurkan oleh Bank Syariah relatif dapat terjaga tingkat pengembalianya, sehingga kemampuan Bank Syariah menghasilkan laba tidak terganggu oleh rasio NPF yang senantiasa berfluktuasi. Hal ini sesuai dengan hasil dari penelitian Nur'aini (2017) dan menurut Saputra dan I Gusti (2016) NPL tidak berpengaruh terhadap profitabilitas.

Berdasarkan latar belakang di atas, dan hasil dari beberapa penelitian yang berbeda-beda dari penelitian terdahulu maka dilakukan penelitian Keterkaitan Efisiensi Operasional dan Pembiayaan Bermasalah dalam Mempengaruhi Profitabilitas Bank Umum Syariah.

\section{KAJIAN PUSTAKA}

\section{Profitabilitas}

Profitabilitas merupakan kemampuan perusahaan maupun bank untuk memperoleh laba secara efektif dan efisien. Salah satu alat ukur tingkat profitabilitas adalah dengan menggunakan Return On Asset (ROA). Return On Asset (ROA) mengukur efektivitas perusahaan dalam 
memanfaatkan seluruh sumber dayanya. ROA juga merupakan rasio yang digunakan untuk mengetahui kemampuan bank dalam menghasilkan keuntungan dari pengelolaan aset yang dimiliki oleh bank. Return On Asset (ROA) merupakan rasio profitabilitas yang digunakan untuk mengukur efektifitas perusahaan di dalam menghasilkan keuntungan dengan memanfaatkan asset yang dimilikinya (Fariza dan Widati, 2017).

Menurut Karya dan Rakhman dalam Suryani (2012) tingkat profitabilitas bank syariah di Indonesia merupakan yang terbaik diukur dari rasio laba terhadap asset (ROA), baik untuk kategori bank yang full fledge maupun untuk kategori Unit Usaha Syariah. Menurut Dendawijaya (2009) ROA digunakan untuk mengukur profitabilitas bank karena Bank Indonesia sebagai pembina dan pengawas perbankan lebih mengutamakan nilai profitabilitas suatu bank, diukur dengan asset yang dananya sebagian besar dari dana simpanan masyarakat. Semakin besar ROA suatu bank, semakin besar pula tingkat keuntungan yang dicapai bank, dan semakin baik pula posisi bank dari segi penggunaan aset.

Return on Assets mengukur kemampuan perusahaan dalam memanfaatkan aktivanya untuk memperoleh laba. Menurut Prastowo (2008) rasio ini mengukur tingkat kembalian investasi yang telah dilakukan oleh perusahaan dengan menggunakan seluruh dana (aktiva) yang dimilikinya.

Ukuran yang sering digunakan untuk menghitung Return on Assets (ROA) adalah:

\section{ROA = Laba Bersih Setelah Pajak $\quad X 100 \%$ Total Aset}

\section{Efisiensi Operasional}

Efisiensi operasional dapat diukur dengan cara membagi biaya operasional dengan pendapatan operasional (BOPO). BOPO merupakan rasio perbandingan antara biaya operasional dengan pendapatan operasional. Rasio BOPO juga termasuk dalam kategori rentabilitas (earning) yang dapat mengukur kemampuan perusahaan dalam menghasilkan laba selama periode tertentu (Munawir, 2010). Menurut Saputra dan I Gusti (2016) BOPO digunakan untuk mengukur tingkat efisiensi dan kemampuan bank dalam malakukan kegiatan operasinya. 
Menurut Bank Indonesia melalui SE BI No.6/73/Intern/2004 Rasio ini bertujuanuntuk mengukur kemapuan pendapatan operasional dalam menutup biayaoperasional. Rasio yang meningkat mencerminkan kurang mampunya bankdalam menekan biaya operasional dan meningkatkan pendapatan operasionalnyayang dapat menimbulkan kerugian karena bank kurang efisien dalam mengelolausahanya.

Siamat (2002) menyatakan pengertian rasio Biaya Operasional terhadap Pendapatan Operasional (BOPO) adalah Rasio efisiensi yang digunakan untuk mengukur kemampuan manajemen bank dalammengendalikan biaya operasional terhadap pendapatan operasional.

BOPO dirumuskan sebagai berikut:

$\mathrm{BOPO}=\frac{\text { Biay a Operasional X } 100 \%}{\text { Pendapatan Operasional }}$

Biaya operasional dihitung berdasarkan penjumlahan dari total bebanbunga dan total beban operasional lainnya. Pendapatan operasional adalahpenjumlahan dari total pendapatan bunga dan total pendapatan operasional lainnya.

Dendawijaya (2009) terdapat beberapa komponen pendapatandan biaya opersional dapat dijelaskan sebagai berikut:

1. Pendapatan Operasional

2. Beban Operasional

Adapun penjelasan dari kedua hal tersebut dapat diuraikan sebagai berikut :

1. Pendapatan Operasional

Pendapatan operasional terdiri atas semua pendapatan yang merupakan hasil. Biaya operasional merupakan biaya yang dikeluarkan oleh bank dalamrangka menjalankan aktivitas usaha pokoknya (seperti biaya bunga, biaya tenaga kerja, biaya pemasaran).

2. Beban Operasional

Beban operasional adalah semua biaya yang berhubungan langsung dengan kegiatan usaha bank langsung dari kegiatan usaha bank yang benar-benar telah diterima. Pendapatan operasional merupakan pendapatan utama bank yaitu pendapatan bagi hasil yang diperoleh 
dari penempatan dana dalambentuk pembiayaan dan penempatan operasi lainnya.

\section{Pembiayaan Bermasalah}

Pembiayaan bermasalah atau kredit bermasalah adalah kegiatan utama dari sebuah bank untuk mendapatkan keuntungan, tetapi memiliki resiko berupa tidak lancarnya pembayaran kredit dikarenakan faktor kesengajaan atau ketidak mampuan nasabah pembiayaan dalam melunasi pinjaman.

Dalam Peraturan Bank Indonesia tentang Penilaian Kualitas Bank Umum yang melaksanakan kegiatan usaha berdasarkan prinsip syariah pasal 9 ayat (2),bahwa kualitas aktiva produktif dalam bentuk pembiayaan dibagi dalam 5 golongan yaitu lancar (L), dalam perhatian khusus (DPK), kurang lancar (KL), diragukan (D), Macet (M).

Adapun penggolongan dari kualitas pembiayaan pada nasabah adalah sebagai berikut:

1. Pembiayaan Lancar (Pass)

Pembiayaan yang digolongkan lancar, apabila memenuhi kriteria sebagai berikut:

a. Pembayaran angsuran pokok/atau bunga tepat waktu.

b. Memiliki mutasi rekening yang aktif.

c. Bagian dari pembiayaan yang dijamin dengan agunan tunai (cash collateral)

2. Perhatian khusus (Special Mention)

Pembiayaan yang digolongkan kedalam pembiayaan dalam perhatian khusus apabila memenuhi kriteria sebagai berikut:

a. Terdapat tunggakan angsuran pokok dan/atau bunga yang belum melampaui 90 hari.

b. Kadang-kadang terjadi cerukan.

c. Mutasi rekening relatif aktif.

d. Jarang terjadi pelanggaran terhadap kontrak yang diperjanjikan.

e. Didukung oleh pinjaman baru.

3. Kurang Lancar (Substandard)

Pembiayaan yang digolongkan kedalam pembiayaan kurang lancar apabila memenuhi kriteria sebagai berikut:

a. Terdapat tunggakan angsuran pokok dan/atau bunga yang telah melampaui 90 hari. 
b. Sering terjadi cerukan.

c. Frekuensi mutasi rekening relatif rendah.

d. Terjadi pelanggaran terhadap kontrak yang diperjanjikan lebih dari 90 hari.

e. Terdapat indikasi masalah keuangan yang dihadapi debitur.

f. Dokumentasi pinjaman yang lemah.

4. Diragukan (Doubtful)

Pembiayaan yang digolongkan kedalam pembiayaan yang diragukan apabila memenuhi kriteria sebagai berikut:

a. Terdapat tunggakan anguran pokok dan/atau bunga yang telah melampaui 180 hari.

b. Terjadi cerukan yang bersifat permanen.

c. Terjadi wanprestasi lebih dari 180 hari.

d. Terjadi kapitalisasi bunga.

e. Dokumentasi hukum yang lemah baik untuk perjanjian pembiayaanmaupun pengikatan jaminan.

5. Macet (Loss)

Pembiayaan yang digolongkan kedalam pembiayaan macet apabila memenuhi kriteria sebagai berikut:

a. Terdapat tunggakan angsuran pokok dan/atau bunga yang telah melampaui 270 hari.

b. Kerugian operasional ditutup dengan pinjaman baru.

c. Dari segi hukum maupun kondisi pasar, jaminan tidak dapat dicairkan pada nilai wajar.

Yang dikategorikan pembiayaan bermasalah adalah kualitas pembiayaan yang masuk golongan Kurang Lancar, Diragukan dan Macet, disebut juga dengan pembiayaan tidak berprestasi (Non Performance Finance/NPF). Pada bank syariah istilah yang digunakan adalah Non Performing Finance (NPF) karena dalam syariah menggunakan prinsip pembiayaan.

Rahman dan Rochmanika (2012) disebutkan berdasarkan Surat Edaran Bank Indonesia Nomor 12/11/DPNP tanggal 31 Maret 2010, pembiayaan dalam hal ini adalah pembiayaan yang diberikan kepada pihak ketiga dan tidak termasuk pembiayaan kepada bank lain yang dihitung berdasarkan nilai tercatat dalam neraca per posisi tidak disetahunkan. Sedangkan pembiayaan bermasalah adalah kredit dengan 
kualitas kurang lancer, diragukan, dan macet yang dihitung berdasarkan nilai tercatat dalam neraca per posisi tidak disetahunkan. Menurut Hadiyati \& Baskara (2013), NPF secara luas dapat diartikan sebagai suatu kredit pembayaran yang dilakukan tidak lancar dan tidak mencukupi kewajiban minimal yang ditetapkan sampai dengan kredit yang sulit untuk dilunasi atau bahkan tidak dapat ditagih. Standar terbaik NPF menurut Bank Indonesia adalah bila NPF berada dibawah $5 \%$.

NPF dirumuskan sebagai berikut:

$$
\begin{gathered}
\text { NPF }=\underset{\text { Kredit Bermasalah }}{\text { X 100\% }} \\
\text { TotalKredit }
\end{gathered}
$$

\section{Model Hipotesis Penelitian}

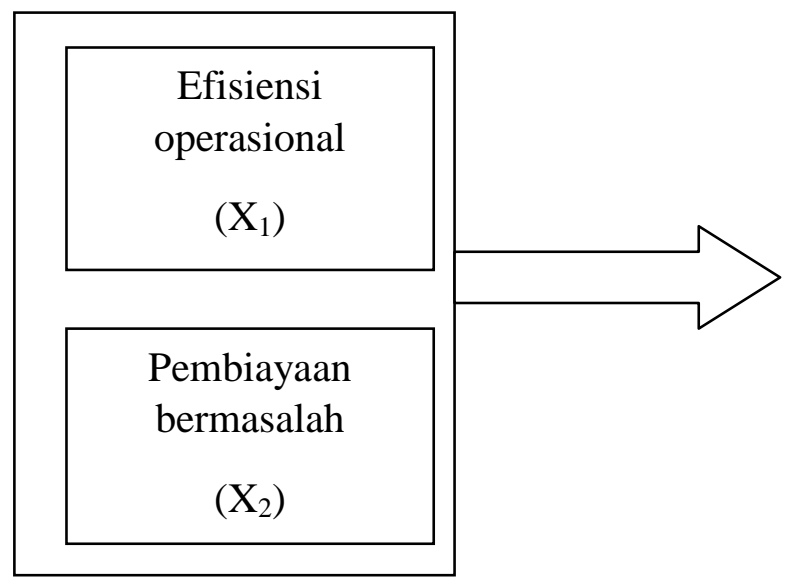

Profitabilitas

\section{Hipotesis Penelitian}

$\mathrm{H}_{1}$ : Efisiensi operasional berpengaruh terhadap profitabilitas bank umum syariah.

$\mathrm{H}_{2}$ : Pembiayaan bermasalah berpengaruh terhadap profitabilitas bank umum syariah.

$\mathrm{H}_{3}$ : Efisiensi operasional dan pembiayaan bermasalah berpengaruh terhadap profitabilitas pada bank umum syariah. 


\section{METODE}

Penelitian ini merupakan jenis penelitian model korelasi multiple dengan menggunakan pendekatan kuantitatif, dan tekhnik korelasional. Data yang digunakan adalah data sekunder dengan melihat laporan keuangan tahunan perbankan syariah yang terdaftar di Bank Indonesia selama tahun 2012 sampai 2016yang diakses melalui situs Bank Indonesia yaitu www.bi.go.id dan www.ojk.go.id maupun situs masingmasing bank yang dijadikan sampel dalam penelitian ini. Populasi dalam penelitian ini adalah bank umum syariah yang terdaftar di Bank Indonesia. Sampel yang dipilih diperoleh dengan menggunakan teknik purposive sampling, yaitu dilakukan dengan cara mengambil sampel dari populasi berdasarkan kriteria tertentu (Ghozali, 2009). . Dengan kriteria a. Perbankan syariah yang termasuk dalam kategori Bank Umum Syariah yang terdaftar di Bank Indonesia (BI) ; b.Bank Umum Syariah yang memiliki dan mempublikasikan laporan tahunan berturut-turut di website Bank Indonesia dan website Otoritas Jasa Keuangan (OJK); dan c. Bank Umum Syariah yang tidak memiliki nilai BOPO, NPF dan ROA negatif. Dari kriteria yang ditetapkan terdapat 8 Bank Umum Syariah yang memenuhi kriteria dan dapat dijadikan sample dengan tahun pengamatan $2012-2016$.

\section{HASIL PENELITIAN}

Keterkaitan secara parsial Efisiensi Operasional dan Pembiayaan Bermasalah terhadap Profitabilitas.

Tabel 3

Persamaan Regresi Berganda

Coefficients $^{a}$

\begin{tabular}{|c|c|c|c|c|c|c|}
\hline \multirow{2}{*}{\multicolumn{2}{|c|}{ Model }} & \multicolumn{2}{|c|}{$\begin{array}{c}\text { Unstandardized } \\
\text { Coefficients }\end{array}$} & \multirow{2}{*}{\begin{tabular}{|c|}
$\begin{array}{c}\text { Standardized } \\
\text { Coefficients }\end{array}$ \\
Beta
\end{tabular}} & \multirow[t]{2}{*}{$\mathrm{t}$} & \multirow[t]{2}{*}{ Sig. } \\
\hline & & B & Std. Error & & & \\
\hline \multirow{3}{*}{1} & $\begin{array}{l}\text { (Constant } \\
\text { ) }\end{array}$ & 7,258 & ,802 & & 9,047 & ,000 \\
\hline & BOPO &,- 069 & 010 &,- 793 & $-7,077$ & ,000 \\
\hline & NPF &,- 023 & ,069 &,- 036 &,- 325 & ,747 \\
\hline
\end{tabular}

a. Dependent Variable: ROA

Sumber Output SPSS, data diolah, 2017 
Berdasarkan tabel di atas dapat diketahui persamaan regresinya yaitu :

$\hat{Y}=\mathrm{a}+\mathrm{b}_{1} \mathrm{X}_{1}+\mathrm{b}_{2} \mathrm{X}_{2}+\mathrm{e}$

Persamaan regresi tersebut dapat diinterpretasikan sebagai berikut :

1. Konstanta sebesar $=7,258$ berarti jika nilai BOPO $\left(X_{1}\right)$ dan NPF $\left(X_{2}\right)$, bernilai tetap atau 0 , maka nilai $\mathrm{ROA}(\mathrm{Y})$ adalah 7,258.

2. Koefisien regresi variabel BOPO $\left(\mathrm{X}_{1}\right)$ sebesar $-0,069$ berarti jika variabel independen lain nilainya tetap dan BOPO naik 1 satuan, maka ROA (Y) akan mengalami penurunan sebesar -0,069 satuan. Koefisien bernilai negatif artinya terjadi hubungan negatif antara variabel independen dengan variabel dependen, semakin naik BOPO semakin turun ROA, begitupun sebaliknya. Dari hasil uji $\mathrm{t}$ nilai $\mathrm{t}$ hitung sebesar $-7,077$ dengan nilai signifikansi sebesar 0,000. Karena nilai signifikansi lebih kecil dari 5\% dan nilai t hitung $-7,077$ lebih besar dari t tabel 2,428 maka hipotesis diterima berarti biaya operasional pendapatan operasional (BOPO) berpengaruh negatif secara parsial terhadap Return on Asset (ROA) pada Bank Umum Syariah. Hal ini menunjukkan bahwa tingkat BOPO yang menurun menunjukkan semakin tinggi efisiensi operasional yang dicapai perusahaan, yang artinya semakin efisien aktiva bank dalam menghasilkan keuntungan.

3. Koefisien regresi variabel NPF $\left(X_{2}\right)$ sebesar $-0,023$. Koefisien bernilai negatif artinya terjadi hubungan yang berlawanan arah antara variabel independen dengan variabel dependen, semakin tinggi tingkat NPF maka akan menurun tingkat ROA begitu juga sebaliknya. Hal ini bisa diartikan jika variabel independen lain nilainya tetap dan NPF mengalami kenaikan 1 satuan, maka ROA (Y) akan mengalami penurunan sebesar -0,023 satuan.Dari hasil uji $t, t$ hitung sebesar $-0,325$ dengan nilai signifikansi sebesar 0,747 . Karena nilai signifikansi lebih besar dari 5\% dan nilai t hitung -0,325 lebih kecil dari $\mathrm{t}$ tabel 2,428 maka hipotesis ditolak berartinon performing finance (NPF) tidak berpengaruh signifikan terhadap Return on Asset (ROA) pada Bank Umum Syariah. Pada periode penelitian tingkat Non Performing Financing (NPF) perbankan syariah masih tergolong rendah, yaitu di bawah $5 \%$. Sehingga perlu adanya kehatihatian pihak perbankan dalam menjalankan fungsinya. Risiko berupa kesulitan pengembalian pembiayaan oleh debitur dengan jumlah yang cukup besar dapat mempengaruhi kinerja perbankan. Terdapatnya 
pembiayaan bermasalah tersebut menyebabkan pembiayaan yang disalurkan banyak yang tidak memberikan hasil.

Keterkaitan secara simultan Efisiensi Operasional dan Pembiayaan Bermasalah terhadap Profitabilitas.

Tabel 4

Keterkaitan secara simultan Efisiensi Operasional dan Pembiayaan Bermasalah terhadap Profitabilitas.

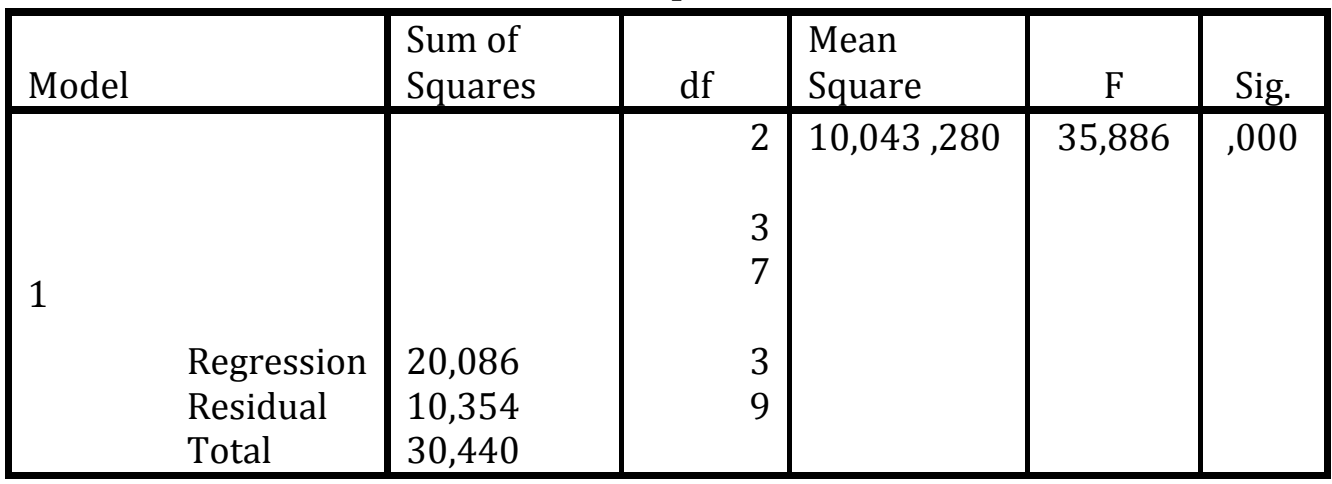

Dari hasil uji f nilai $F$ hitung diperoleh sebesar 35,886 > F tabel sebesar 2,86 dengan tingkat signifikansi $0,000<0,005$. Karena tingkat signifikansi lebih kecil dari 0,005 maka Ha diterima dan menolak Ho (hipotesis ditolak) sehingga dapat disimpulkan bahwa biaya operasional pendapatan operasional (BOPO) dan non performing finance (NPF) berpengaruh secara simultan (bersama-sama) terhadap Return on Asset (ROA) Bank Umum Syariah tahun 2012-2016.

Kontribusi Efisiensi Operasional dan Pembiayaan Bermasalah terhadap Profitabilitas.

Tabel 5 Determinasi Adjusted R Squere

Model Summaryb

\begin{tabular}{|l|r|r|r|r|c|}
\hline Model & $\mathrm{R}$ & R Square & $\begin{array}{c}\text { Adjusted R } \\
\text { Square }\end{array}$ & $\begin{array}{c}\text { Std. Error of } \\
\text { the Estimate }\end{array}$ & $\begin{array}{c}\text { Durbin- } \\
\text { Watson }\end{array}$ \\
\hline 1 &, $812^{\mathrm{a}}$ &, 660 &, 641 &, 52901 & 1,876 \\
\hline
\end{tabular}

a. Predictors: (Constant), NPF, BOPO

b. Dependent Variable: ROA

Sumber Output SPSS, data diolah, 2017 
Berdasarkan tabel di atas diperoleh adjusted R Square sebesar 0,641atau $64,1 \%$ hal ini berarti bahwa prosentase kontribusi Efisensi Operasional (BOPO) dan Pembiayaan Bermasalah (NPF) terhadap ROAsebesar 64,1\% sedangkan sisanya sebesar 35,9\% dipengaruhi oleh variabel lain yang tidak dijelaskan dalam penelitian ini.

\section{KESIMPULAN}

Berdasarkan hasil penelitian dan pembahasan, maka dapat diambil kesimpulan sebagai berikut : Efisiensi operasional berpengaruh negatif terhadap Profitabilitas pada Bank Umum Syariah. Hal ini menunjukkan bahwa tingkat BOPO yang menurun menunjukkan semakin tinggi efisiensi operasional yang dicapai perusahaan, yang artinya semakin efisien aktiva bank dalam menghasilkan keuntungan. Pembiayaan bermasalah tidak berpengaruh terhadap tingkat profitabilitas pada Bank Umum Syariah. Selanjutnya secara simultan Efisiensi Operasional dan Pembiayaan Bermasalah berpengaruh terhadap Profitabilitas.

\section{DAFTAR PUSTAKA}

Bambang Agus. 2010. Faktor-faktor yang berpengaruh terhadap tingkat profitabilitas Bank Umum Syariah. Jurnal Akuntansi, Manajemen Bisnis dan Sektor Publik. Volume.7 No.1 2010. Hal. 63-79

Dendawijaya, L. 2009. Manajemen Perbankan. Penerbit Ghalia Indonesia. Jakarta

Ghozali Imam. 2009. Aplikasi Analisis multivariate dengan Program SPSS. Badan Penerbit Undip.

Hadiyati, P., \& Baskara, R.A. (2013). Pengaruh Non Performing Financing Pembiayaan Mudharabah dan Musyarakah Pada Bank Muamalat Indonesia. e-Jurnal Manajemen dan Bisnis. 1(1).

http://www.bi.go.id

http://www.ojk.go.id

Nur'aini Indah. 2017. Pengaruh Kecukupan Modal,Risiko Pembiayaan,Efisiensi Operasional dan Likuiditas Terhadap Profitabilitas. Riset Akuntansi dan Keuangan Indonesia. Vol.2 
Nur'aini, I. 2017. Pengaruh Kecukupan Modal, Risiko Kredit, Efisiensi Operasional Dan Likuiditas Terhadap Profitabilitas (Survey pada Bank Umum Konvensional di Indonesia Periode 2011-2015). Skripsi. Universitas Muhammadiyah Surakarta

Nurul, A.F., Listyorini, W.W. 2017. Analisa Profitabilitas, Likuiditas, Pertumbuhan Penjualan, Struktur Aktiva Dan Kebijakan Dividen Terhadap Struktur Modal. Prosiding Seminar Nasional Multi Disiplin dan Call Papers UNISBANK ke 3.

Munawir. 2010. Analisis Laporan Keuangan. Yogyakarta: Liberty

Peraturan Bank Indonesia Nomor 8/21/PBI/2006 tanggal 5 Oktober 2006.

Prastowo (2008). Analisis Laporan Keuangan (Konsep dan Aplikasi). Edisi Kedua, Yogyakarta, UUP STIM YKPN.

Rahman, F., Rochmanika, R. 2012. Pengaruh Pembiayaan Jual Beli, Pembiayaan Bagi Hasil, dan Rasio Non Performing Financing terhadap Profitabilitas Bank Umum Syariah di Indonesia. Jurnal Iqtishoduna. Vol.8 No.1

Sani Achmad. 2013. Role of Procedural Justice, Organizational Commitment and Job Satisfaction on Job Performance: The Mediating Effects of Organizational Citizenship Behavior. International Journal of Business and Management. Vol.8 No.15. p.57-67

Saputra, I. M.H.E dan I Gusti, A.N.B. 2016. Pengaruh Kecukupan Modal, Risiko Kredit, Biaya Operasional, Pendapatan Operasional pada Profitabilitas Bank. Bali. Universitas Udayana Bali.

Siamat, D. 2002. Manajemen Lembaga Keuangan. Edisi 2. Jakarta: Lembaga Penerbit FEUI.

Suryani. 2012. Analisis pengaruh financing to deposit ratio (FDR) terhadap profitabilitas perbankan syariah di Indonesia (rasio keuangan pada bus dan uus periode 2008-2010). Economica. Vol 2. Edisi 2.

Surat Edaran Bank Indonesia Nomor 6/23/DPNP tanggal 31 Mei 2004.

Wibowo, E.S., Syaichu. 2013. Analisis Pengaruh Suku Bunga, Inflasi, CAR, BOPO, NPF Terhadap Profitabilitas Bank Syariah. Diponegoro Journal of Management. Hal.1-10

Zakiy, F.S., Ridwan, A.M., Sani, A. 2018. Characteristics and islamic Economics Rules Of Muslem Families Economy In The Modern Era Based On Maqashid Syariah Perspective. Thesis. Pasca Sarjana Uin Maulana Malik Ibrahim Malang. Tidak Dipublikasikan. 